\title{
PENERAPAN SISTEM AKUNTANSI PEMERINTAH (SAP) BERBASIS AKRUAL DALAM PENGAMBILAN KEPUTUSAN INTERNAL DAN KUALITAS PELAPORAN KEUANGAN PEMERINTAH DAERAH
}

\author{
THE EFFECT OF THE IMPLEMENTATION OF ACCRUAL BASED GOVERNMENT \\ ACCOUNTING STANDARDS (SAP) ON THE INTERNAL-DECISION MAKING AND THE \\ QUALITY OF FINANCIAL REPORTING ON LOCAL GOVERNMENT
}

\author{
Dini Lestari', Sri Rahayu² \\ Telkom University - Bandung \\ Email : dinilestari27@gmail.com
}

\begin{abstract}
ABSTRAK
Penelitian ini bertujuan untuk menganalisis pengaruh penerapan SAP berbasis akrual terhadap pengambilan keputusan internal dan kualitas pelaporan keuangan pemerintah daerah. Subjek dalam studi ini adalah Satuan Kerja Perangkat Daerah yang terdiri dari dinas dan badan Kota Bandung dengan total sampel sebanyak 83 responden. Penelitian ini menggunakan metode kuantitatif dengan data primer. Metode analisis yang dipakai adalah analisis regresi linier sederhana menggunakan perangkat lunak SPSS versi 23. Hasil penelitian menunjukkan bahwa secara parsial penerapan SAP berbasis akrual berpengaruh signifikan terhadap pengambilan keputusan internal dan kualitas pelaporan keuangan pemerintah daerah.

Kata Kunci: Akuntansi Sektor Publik, Standar Akuntansi Pemerintah, Basis Akrual, Pengambilan Keputusan Internal, Kualitas Pelaporan Keuangan
\end{abstract}

\begin{abstract}
The purpose of this study is to analysis the implementation of accrual-based SAP towards internal decision making and the quality of financial reporting on local government. The subject of this study is the Regional Work Units consists of the agency and department Bandung City with total sample of 83 respondent. This study uses quantitative methods with primary data. The analysis method in this research is simple linear regression using software SPSS version 23. The results showed that in the partial implementation of SAP-based accruals on the Bandung city government has a significant influence on internal decision making and quality of financial reporting on local government.
\end{abstract}

Keywords: Public Sector accounting, government accounting standards, accrual based, Internal decision making, quality financial reporting, 


\section{PENDAHULUAN}

Laporan keuangan yang disajikan oleh pemerintah daerah harus sesuai dengan standar yang berlaku, yaitu sesuai dengan SAP yang telah ditetapkan dalam Peraturan Pemerintah nomor 24 tahun 2005 yang memuat pengantar Standar Akuntansi Pemerintahan, dijabarkan dalam bentuk Pernyataan Standar Akuntansi Pemerintahan (PSAP) dan berdasarkan Kerangka Konseptual Akuntansi Pemerintahan. Diperkuat dengan Peraturan Mendagri No. 64 Tahun 2013 yang mengatur tentang kewajiban pemerintah daerah untuk menyusun persiapan implementasi Standar Akuntansi Pemerintahan (SAP) berbasis akrual. SAP Berbasis Akrual adalah SAP yang mengakui pendapatan, beban, aset, utang, dan ekuitas dalam pelaporan finansial berbasis akrual, serta mengakui pendapatan, belanja, dan pembiayaan dalam pelaporan pelaksanaan anggaran berdasarkan basis yang ditetapkan dalam APBN/APBD (PP No 71 Tahun 2010). Angelicca (2019) dan Ferryono, Sutaryo (2017) menyatakan bahwa SAP berperan untuk membantu para penyusun laporan keuangan pemerintah daerah mencapai laporan keuangan yang berkualitas baik serta mempermudah pengambilan keputusan internal. Tujuan pelaporan keuangan disektor publik harus memberikan informasi yang berguna untuk pengambilan keputusan di samping menunjukkan akuntabilitasnya. Untuk menunjang pengambilan keputusan yang tepat, maka laporan keuangan yang dibuat harus memenuhi karakteristik kualitatif yang mencerminkan bahwa kualitas laporan keuangan pemerintah daerah sudah ררาtercapai dengan baik dan memenuhi tujuannya. Kualitas laporan keuangan yang dimaksud sesuai dengan PP No. 71 Tahun 2010 adalah relevan, andal, dapat dibandingkan dan dapat dipahami. Dalam keterkaitan antara penerapan SAP berbasis akrual, pengambilan keputusan internal dan kualitas pelaporan keuangan pemerintah daerah, dibuktikan dengan fenomena dimana Pemerintah Kota Bandung mengalami defisit anggaran di tahun 2019 dimana defisit anggaran salah satu bentuk dari penyusunan anggaran yang kurang efisien yang tercermin dari informasi laporan keuangan. Selain itu, fenomena Pemerintah Kota Bandung meraih opini Wajar Tanpa Pengecualian (WTP) dari hasil pemeriksaan Laporan Keuangan Pemerintah Daerah (LKPD) untuk pertama kalinya dalam sejarah, karena berhasil menuntaskan salah satu dari kendala yang selama ini dialami oleh Pemerintah Kota Bandung, yaitu penyusunan informasi pencatatan terkait akuntansi aset dan akuntansi kewajiban sebagaimana diterangkan dalam PSAP No. 7 dan PSAP No. 9. Hal ini menunjukkan bahwa Penerapan SAP berbasis akrual berperan penting dalam menyusun laporan keuangan sehingga membantu menghasilkan informasi yang relevan dan andal untuk kualitas pelaporan keuangan yang baik serta mampu menyajikan informasi yang bermanfaat bagi para pengguna laporan dalam pengambilan keputusan internal.

Dari hasil penelitian yang dilakukan sebelumnya, terjadi inkonsistensi hasil penelitian. Menurut penelitian Andhayani (2017), penerapan SAP berbasis akrual dalam pengelolaan keuangan daerah dinilai kurang efektif, karena kurangnya sinergi, kemauan, serta komitmen dari seluruh pengelola keuangan. Namun, menurut Purwanti (2017) dan Trihani (2018) meskipun penerapan SAP berbasis akrual menguras tenaga dan dianggap sebagai keterpaksaan, namun disisi lain bisa dianggap berkah karena bisa mendapatkan opini WTP dari penyajian laporan keuangan yang baik. Dalam penelitian Salam dan Sutaryo (2019), menyatakan bahwa pelaporan keuangan berdasar SAP berbasis akrual tidak berpengaruh signifikan terhadap pengambilan keputusan internal, sedangkan dalam penelitian Ferryono, Sutaryo (2017) menyatakan bahwa basis akuntansi akrual berpengaruh signifikan terhadap pengambilan keputusan internal pemerintah daerah. Dalam penelitian Anggriawan, Yudianto (2018) disebutkan bahwa penerapan SAP basis akrual berpengaruh positif terhadap kualitas laporan keuangan pemerintah daerah, namun penelitian Rahmah, Zulkifli (2018) menyebutkan bahwa penerapan SAP basis akrual tidak berpengaruh terhadap kualitas laporan keuangan pemerintah daerah. 
Adapun penelitian ini bertujuan untuk menguji secara parsial pengaruh penerapan SAP berbasis akrual terhadap pengambilan keputusan internal dan kualitas pelaporan keuangan pemerintah daerah.

\section{LANDASAN TEORI}

\section{Pelaporan Keuangan Pemerintah Daerah}

Dalam Peraturan Pemerintah Nomor 71 Tahun 2010, Kerangka Konseptual Akuntansi Pemerintahan adalah konsep dasar penyusunan dan pengembangan Standar Akuntansi Pemerintahan, dan merupakan acuan bagi Komite Standar Akuntansi Pemerintahan, penyusun laporan keuangan, pemeriksa, dan pengguna laporan keuangan dalam mencari pemecahan atas sesuatu masalah yang belum diatur dalam Pernyataan Standar Akuntansi Pemerintahan (PSAP). Menurut Pernyataan Standar Akuntansi Pemerintahan (PSAP) Nomor 01, tujuan umum laporan keuangan adalah untuk menyajikan informasi mengenai posisi keuangan, realisasi anggaran, arus kas, dan kinerja keuangan suatu entitas pelaporan yang bermanfaat bagi para pengguna dalam membuat dan mengevaluasi keputusan mengenai alokasi sumber daya. Pelaporan keuangan untuk tujuan umum juga mempunyai peranan prediktif dan porspektif, menyediakan informasi yang berguna untuk memprediksi besarnya sumber daya yang dibutuhkan untuk operasi yang berkelanjutan, sumber daya yang dihasilkan dari operasi yang berkelanjutan, serta risiko dan ketidakpastian yang terkait.

\section{Sistem Akuntansi Pemerintahan Berbasis Akrual}

Akuntansi berbasis akrual merupakan international best practice dalam pengelolaan keuangan modern yang sesuai dengan prinsip New Public Management (NPM) yang mengedepankan transparansi dan akuntabilitas pengelolaan keuangan (Karno, 2017). Menurut PP 71 Tahun 2010, basis akrual adalah basis akuntansi yang mengakui pengaruh transaksi dan peristiwa lainnya pada saat transaksi dan peristiwa itu terjadi, tanpa memperhatikan saat kas atau setara kas diterima atau dibayar. (Dalam Ferryono, Sutaryo, 2017). Laporan keuangan yang dihasilkan dari penerapan SAP berbasis akrual diarahkan untuk memberi manfaat lebih baik kepada para pemangku kepentingan (stakeholders), para pengguna, maupun pemeriksa laporan keuangan pemerintah, dibandingkan dengan biaya yang dikeluarkan. Selain itu, basis akrual dapat merepresentasikan reliabilitas, relevansi, dan komparabilitas informasi yang diungkapkan dalam laporan, sehingga dapat dipastikan bahwa informasi telah disajikan secara jujur (Sari dan Putra, 2012 dalam Najati dkk, 2016). Implementasi Standar Akuntansi Pemerintah berbasis akrual menyajikan informasi yang dapat diukur dengan indikator yang dijabarkan oleh Pujanira \& Taman dalam Kusumo, Grani R (2018) dengan penjelasan menurut Permendagri No 64 Tahun 2013 yaitu: 1. PSAP No.1 tentang Penyajian Laporan Keuangan, PSAP No.2 tentang Laporan Realisasi Anggaran Berbasis Kas, PSAP No. 3 tentang Laporan Arus Kas, PSAP No. 4 tentang Catatan Atas Laporan Keuangan, PSAP No. 5 tentang Akuntansi Persediaan, PSAP No. 6 tentang Akuntansi Investasi, PSAP No. 7 tentang Akuntansi Aset Tetap, PSAP No. 8 tentang Akuntansi Konstruksi dalam Pengerjaan, PSAP No. 9 tentang Akuntansi Kewajiban, PSAP No. 10 tentang Koreksi Kesalahan, PSAP No. 11 tentang Laporan Keuangan Konsolidasi, dan PSAP No. 12 tentang Laporan Operasional 


\section{Pengambilan Keputusan Internal}

Laporan keuangan untuk mendukung pembuatan keputusan ekonomi, sosial, politik meliputi informasi yang digunakan untuk (a) Membandingkan kinerja keuangan aktual dengan yang dianggarkan (b) Menilai kondisi keuangan dan hasil-hasil operasi (c) Membantu menentukan tingkat kepatuhan terhadap peraturan perundangan yang terkait dengan masalah keuangan dan ketentuan lainnya, serta (d) Mengevaluasi efisiensi dan efektivitas (Trihani, 2018). Menurut Fatmawati dan Setiawan (2018), informasi yang bermanfaat apabila mempunyai nilai kebermanfaatan keputusan seperti: 1) Menambah pengetahuan keputusan tentang keputusannya dimasa lalu, sekarang, dan masa mendatang; 2) Menambah keyakinan para pemakai mengenai probabilitas terealisasinya suatu harapan dalam kondisi ketidakpastian; 3) Mengubah keputusan atau perilaku pemakai. Informasi keuangan yang tertera dalam laporan keuangan selanjutnya akan dimanfaatkan oleh para eksekutif yang berkepentingan untuk mengambil keputusan internal sebagai dasar dalam pengelolaan manajemen pemerintahan daerah. Indikator pada pengambilan keputusan internal menurut Suhartanto (2013) yaitu untuk: 1) Menyusun perencanaan anggaran 2) Pelaksanaan program pemerintahan 3) Keluaran (output) berupa posisi kekayaan daerah yang digunakan dalam upaya peningkatan kesejahteraan masyarakat secara berkala, dan 40 Evaluasi peningkatan kinerja pada periode selanjutnya.

\section{Kualitas Pelaporan Keuangan Pemerintah Daerah}

Peraturan Pemerintah (PP) No. 71 Tahun 2010 menjabarkan karakteristik kualitatif laporan keuangan adalah ukuran-ukuran normatif yang perlu diwujudkan dalam informasi akuntansi sehingga dapat memenuhi tujuannya. Adapun karakteristik yang merupakan prasyarat normatif yang diperlukan agar laporan keuangan yang dihasilkan dapat memenuhi kualitas yang dikehendaki, yaitu; (1) Relevan: Laporan keuangan dikatakan relevan apabila informasi yang ada dapat mempengaruhi keputusan pengguna yang memiliki: (a) Manfaat umpan balik (feedback value), (b) Manfaat prediktif (predictive value), (c) Tepat waktu, (d) Lengkap, (2) Andal: Informasi yang termuat dalam laporan keuangan bebas dari kesalahan material, menyajikan setiap fakta secara jujur serta dapat diverifikasi, seperti penyajian jujur, dapat diverifikasi dan netralitas, (3) Dapat dibandingkan: Informasi yang ada di dalam laporan keuangan akan lebih berguna jika dapat dibandingkan dengan laporan keuangan periode sebelumnya atau dengan entitas pelaporan lain pada umumnya, (4) Dapat dipahami: Informasi yang disajikan dapat dipahami oleh pengguna dan dinyatakan dalam bentuk serta istilah yang disesuaikan dengan batas pemahaman para pengguna.

\section{Pengembangan Hipotesis}

\section{Pengaruh Penerapan Standar Akuntansi Pemerintah (SAP) Berbasis Akrual terhadap Pengambilan Keputusan Internal}

Pelaporan dengan basis akrual dapat memberikan keuntungan dibandingkan dengan basis kas yang sebelumnya digunakan, yaitu pendapatan yang dihasilkan oleh SAP berbasis akrual lebih tepat dibandingkan dengan basis kas karena informasi yang dihasilkan (pendapatan dan biaya) lebih terkini sehingga akurat dalam memprediksi dan membuat keputusan terkait pendapatan masa depan dan posisi keuangan. Selain itu, basis akrual dapat mengidentifikasi adanya biaya-biaya yang timbul dari kegiatan yang dilakukan sehingga entitas publik bisa mengalokasikan sumber dayanya lebih baik dan efisien juga bisa meningkatkan kinerja. Sehingga, laporan keuangan yang dihasilkan dari basis akrual lebih komprehensif, mudah dimengerti, bernilai lebih terhadap unsur dapat dibandingkan, transparan serta konsisten yang 
dimana sangat membantu para manajemen untuk mengambil suatu keputusan yang lebih rasional. Dalam penelitian yang dilakukan oleh Calmel (2017) dan Ferryono, Sutaryo (2017) menyatakan bahwa penerapan SAP berbasis akrual berpengaruh positif terhadap pengambilan keputusan internal. Dari uraian tersebut, maka ditarik hipotesis sebagai berikut:

\section{H1 : Penerapan Sistem Akuntansi Pemerintahan (SAP) Berbasis Akrual berpengaruh positif terhadap Pengambilan Keputusan Internal}

\section{Pengaruh Penerapan Standar Akuntansi Pemerintah (SAP) Berbasis Akrual terhadap Kualitas Pelaporan Keuangan Pemerintah Daerah}

Standar Akuntansi Pemerintah (SAP) adalah sekumpulan prinsip yang harus diterapkan dalam menyusun laporan keuangan demi mendapatkan hasil laporan yang berkualitas baik sesuai dengan ukuran normatif yang disebutkan dalam PP No 71 Tahun 2010. Dengan menerapkan SAP basis akrual, informasi yang ada di dalam Laporan Keuangan Pemerintah Daerah sesuai dengan kriteria karakteristik kualitatif karena menjabarkan seluruh pengakuan pendapatan LO dan beban dalam laporan operasional, pengakuan ekuitas dalam neraca yang berasal dari laporan perubahan ekuitas, pengakuan surplus/defisit LO dalam laporan perubahan ekuitas, perbandingan anggaran dengan realisasi belanja dalam laporan realisasi anggaran, serta penjelasan pos-pos dan akun-akun dalam laporan keuangan secara rinci dan memadai (full disclosure) dalam catatan atas laporan keuangan. Dari sisi sistem, penerapan basis akrual lebih terintegrasi sehingga memudahkan penginputan belanja modal dalam menyusun laporan keuangan yang dimana meningkatkan kualitas informasi yang lebih relevan dan andal.

\section{H2: Penerapan Sistem Akuntansi Pemerintahan (SAP) Berbasis Akrual berpengaruh positif terhadap Kualitas Pelaporan Keuangan Pemerintah Daerah}

\section{METODOLOGI PENELITIAN}

\section{Jenis dan Sumber Data Penelitian}

Jenis data yang digunakan dalam penelitian ini adalah data primer, yaitu data-data yang berasal dari sumber langsung. Data yang digunakan berupa kuesioner penelitian yang dibagikan kepada para sampel penelitian yang ada. Populasi yang digunakan dalam penelitian ini adalah Satuan Kerja Perangkat Daerah (SKPD) berupa dinas dan badan. Pengambilan sampel dilakukan dengan metode sensus sampling. Sampel pada penelitian ini adalah pengelola keuangan SKPD yang terdiri dari Pengguna Anggaran yaitu Kepala SKPD serta Pejabat Penatausahaan Keuangan yang terdiri dari Sekretaris dan Kasubbag Keuangan berjumlah 83 orang. Sampel ini disusun karena setiap level pengelola keuangan berkontribusi terhadap penyusunan informasi akuntansi yang disajikan dalam laporan keuangan serta sebagai pengambilan keputusan internal di tingkat teknis pada satuan kerja

\section{Metode Analisis dan Hipotesisi Penelitian}

Metode analisis data dalam penelitian ini adalah analisis statistik deskriptif dengan model regresi linier sederhana. Untuk pengujian hipotesis menggunakan bantuan software SPSS versi 23. Kemudian, dua uji asumsi klasik dalam penelitian ini meliputi normalitas dan heteroskedastisitas. Penjelasan masing-masing pengujian asumsi klasik akan diuraikan seperti di bawah ini. Lanjutan pengujian untuk metode analisis yang digunakan untuk menguji pengaruh variabel bebas terhadap terikat dengan Uji T dan Uji Determinasi 


\section{Operasional Variabel Penelitian}

\section{Penerapan Standar Akuntansi Pemerintah (SAP) Berbasis Akrual}

SAP Berbasis Akrual adalah SAP yang mengakui pendapatan, beban, aset, utang, dan ekuitas dalam pelaporan finansial berbasis akrual, serta mengakui pendapatan, belanja, dan

pembiayaan dalam pelaporan pelaksanaan anggaran berdasarkan basis yang ditetapkan dalam APBN/APBD (PP No. 71 Tahun 2010). Indikator yang digunakan untuk mengukur penerapan SAP berbasis akrual menggunakan 12 indikator sesuai dengan penelitian yang dilakukan oleh Pujanira dan Taman (2017). Indikator-indikator tersebut adalah sebagai berikut:

1. PSAP No. 1 tentang Penyajian Laporan Keuangan

2. PSAP No. 2 tentang Laporan Realisasi Anggaran Berbasis Kas

3. PSAP No. 3 tentang Laporan Arus Kas

4. PSAP No. 4 tentang Catatan Atas Laporan Keuangan

5. PSAP No. 5 tentang Akuntansi Persediaan

6. PSAP No. 6 tentang Akuntansi Investasi

7. PSAP No. 7 tentang Akuntansi Aset Tetap

8. PSAP No. 8 tentang Akuntansi Konstruksi dalam Pengerjaan

9. PSAP No. 9 tentang Akuntansi Kewajiban

\section{Pengambilan Keputusan Internal}

Pengambilan Keputusan Internal adalah proses memilih prosedur tertentu dari berbagai kemungkinan alternatif yang senantiasa berkaitan dengan sebuah problem dan ingin dicapai suatu pemecahan. Secara harfiah pengambilan keputusan berarti memotong atau memutuskan atau secara praktis mencapai suatu kesimpulan (Winardi,1986:11). Indikator yang digunakan untuk mengukur pengambilan keputusan internal menggunakan 4 indikator sesuai dengan penelitian yang dilakukan oleh Suhartanto (2013) dan Andriani et al (2010). Indikator-indikator tersebut adalah sebagai berikut:

1. Menyusun perencanaan anggaran

2. Pelaksanaan program pemerintahan

3. Keluaran (output) berupa posisi kekayaan daerah dalam upaya peningkatan kesejahteraan masyarakat secara berkala

4. Evaluasi peningkatan kinerja periode selanjutnya

\section{Kualitas Pelaporan Keuangan Pemerintah Daerah}

Peraturan Pemerintah No. 71 Tahun 2010 tentang karakteristik kualitatif laporan keuangan adalah ukuran-ukuran normatif yang perlu diwujudkan dalam informasi akuntansi sehingga dapat memenuhi tujuannya. Indikator yang digunakan untuk mengukur kualitas pelaporan keuangan pemerintah daerah menggunakan 4 indikator sesuai dengan penelitian yang dilakukan oleh Pujanira dan Taman (2017). Indikator-indikator tersebut adalah sebagai berikut:
1. Relevan
2. Andal
3. Dapat dibandingkan
4. Dapat dipahami 
HASIL DAN PEMBAHASAN

Hasil Penelitian

Tabel. 1. Hasil Analisis Statistik Deskriptif

\begin{tabular}{lrrrrrc}
\hline & \multicolumn{1}{c}{$\mathrm{N}$} & \multicolumn{1}{c}{ Min } & \multicolumn{1}{c}{ Max } & \multicolumn{2}{c}{ Mean } & Std. Deviation \\
\cline { 2 - 7 } & Statistic & Statistic & Statistic & Statistic & Std. Error & Statistic \\
Penerapan SAP & 83 & 90 & 125 & 109.84 & 1.037 & 9.446 \\
Akrual & 83 & 33 & 50 & 43.81 & .487 & 4.432 \\
PKI & 83 & 37 & 50 & 44.66 & .444 & 4.049 \\
KPKPD & & & & &
\end{tabular}

Sumber : Output SPSS 23

Pada tabel 1 diatas dapat dilihat hasil uji statistik deskriptif yang terdiri dari jumlah data, nilai minimum, maksimum, mean dan standar deviasi. Variabel Penerapan SAP Akrual memiliki nilai mean sebesar 109,84 lebih besar daripada standar deviasi yaitu sebesar 9,446. Hal tersebut menggambarkan data tidak bervariasi dan cenderung berkelompok. Variabel PKI memiliki nilai mean sebesar 43,81 lebih besar daripada standar deviasi yaitu sebesar 4,432. Hal tersebut menggambarkan data tidak bervariasi dan cenderung berkelompok. Variabel Penerapan SAP Akrual KPKPD memiliki nilai mean sebesar 44,66 lebih besar daripada standar deviasi yaitu sebesar 4,049. Hal tersebut menggambarkan data tidak bervariasi dan cenderung berkelompok.

\section{Analisis Regresi Linier Sederhana}

Hasil analisis regresi linier sederhana dari penelitian ini menghasilkan bentuk persamaan regresi linier sederhana yang pertama sebagai berikut:

$$
Y=5,594+0.348 X
$$

Persamaan tersebut menggambarkan apabila diperkirakan variabel bebas $(X)$ naik sebesar satu unit dan variabel bebas lainnya diperkirakan konstan atau sama dengan nol, maka nilai variabel terikat $(Y)$ diperkirakan dapat naik atau turun sesuai dengan tanda koefisien regresi variabel bebasnya.

Untuk bentuk persamaan regresi linier sederhana yang kedua sebagai berikut:

$$
Y=8,129+0.333 X
$$

Persamaan tersebut menggambarkan apabila diperkirakan variabel bebas $(X)$ naik sebesar satu unit dan variabel bebas lainnya diperkirakan konstan atau sama dengan nol, maka nilai variabel terikat $(Y)$ diperkirakan dapat naik atau turun sesuai dengan tanda koefisien regresi variabel bebasnya.

Uji Parsial (Uji t)

Hal. 81 
Tabel. 2. Uji Parsial Pertama

\begin{tabular}{lrcccc}
\hline & \multicolumn{2}{c}{$\begin{array}{c}\text { Unstandardized } \\
\text { Coefficients }\end{array}$} & $\begin{array}{c}\text { Standardized } \\
\text { Coefficients }\end{array}$ & \multirow{2}{*}{ T } & Sig. \\
\cline { 2 - 4 } Model & \multicolumn{1}{c}{ B } & Std. Error & Beta & & \\
\hline 1 (Constant) & 5.594 & 3.857 & & 1.450 & .151 \\
$\begin{array}{l}\text { Penerapan SAP } \\
\text { Akrual }\end{array}$ & .348 & .035 & .741 & 9.944 & .000 \\
\hline
\end{tabular}

Sumber: Output SPSS 23

Berdasarkan hasil dari tabel 2 untuk hipotesis pertama yaitu variabel Penerapan SAP Berbasis Akrual $(X)$ diperoleh bahwa tingkat signifikansi sebesar 0,000 lebih kecil dari $a=0,05$ atau $0,000<0,05$. Sehingga, Ho ditolak yang artinya bahwa secara parsial variabel Penerapan SAP Berbasis Akrual $(X)$ berpengaruh signifikan positif terhadap Pengambilan Keputusan Internal (Y1).

Tabel. 3. Uji Parsial Kedua

\begin{tabular}{|c|c|c|c|c|c|c|}
\hline \multirow{2}{*}{\multicolumn{2}{|c|}{ Model }} & \multicolumn{2}{|c|}{$\begin{array}{l}\text { Unstandardized } \\
\text { Coefficients }\end{array}$} & \multirow{2}{*}{$\begin{array}{c}\text { Standardized } \\
\text { Coefficients } \\
\text { Beta }\end{array}$} & & \multirow[t]{2}{*}{ Sig. } \\
\hline & & $B$ & Std. Error & & & \\
\hline 1 & (Constan & 8.129 & 3.313 & & 2.454 & . 016 \\
\hline & Penerapan SAP Akrual & .333 & .030 & .776 & 11.069 & .000 \\
\hline
\end{tabular}

Berdasarkan hasil perhitungan dari tabel 3 untuk hipotesis kedua yaitu variabel Penerapan SAP Berbasis Akrual $(X)$ diperoleh bahwa tingkat signifikansi sebesar 0,000 lebih kecil dari $\alpha=$ 0,05 atau $0,000<0,05$. Sehingga, Ho ditolak yang artinya bahwa secara parsial variabel Penerapan SAP Berbasis Akrual $(X)$ berpengaruh signifikan positif terhadap Kualitas Pelaporan Keuangan Pemerintah Daerah (Y2).

\section{Koefisien Determinasi}

Pengujian hipotesis untuk membuktikan hasil penelitian yang memiliki pengaruh berdasarkan hipotesis yang telah ditetapkan sebelumnya. Hasil output SPSS dibuktikan dalam tabel dibawah ini.

Tabel. 4. Koefisien Determinasi Pertama

\begin{tabular}{lrrrr}
\hline Model & $\mathrm{R}$ & R Square & $\begin{array}{c}\text { Adjusted R } \\
\text { Square }\end{array}$ & $\begin{array}{l}\text { Std. Error of } \\
\text { the Estimate }\end{array}$ \\
\hline 1 & $.741^{\mathrm{a}}$ & .550 & .544 & 2.993 \\
\hline Sumber : Output SPSS 23 & & &
\end{tabular}

Untuk besarnya pengaruh variabel independen terhadap variabel dependen dapat dilihat berdasarkan nilai koefisien determinasi pada tabel 4 dimana nilai Adjusted R Square adalah sebesar 0,544 atau 54,4\%. Hal tersebut menunjukkan bahwa variabel independen yaitu Penerapan SAP Berbasis Akrual mempengaruhi variabel dependen Pengambilan Keputusan Internal (Y1) sebesar 54,4\%. Sedangkan sisanya dijelaskan oleh variabel lain diluar penelitian. 
Tabel. 5. Koefisien Determinasi Kedua

\begin{tabular}{lcccc}
\hline Model & $\mathrm{R}$ & $\mathrm{R}$ Square & $\begin{array}{c}\text { Adjusted R } \\
\text { Square }\end{array}$ & $\begin{array}{c}\text { Std. Error of the } \\
\text { Estimate }\end{array}$ \\
\hline 1 & $.776^{\mathrm{a}}$ & .602 & .597 & 2.570 \\
\hline Sumber : Output SPSS 23 & & &
\end{tabular}

Untuk besarnya pengaruh variabel independen terhadap variabel dependen dapat dilihat berdasarkan nilai koefisien determinasi pada tabel 5 dimana nilai Adjusted $\mathrm{R}$ Square adalah sebesar 0,597 atau $59,7 \%$. Hal tersebut menunjukkan bahwa variabel independen yaitu Penerapan SAP Berbasis Akrual mempengaruhi variabel dependen Kualitas Pelaporan Keuangan Pemerintah Daerah (Y2) sebesar 59,7\%. Sedangkan sisanya dijelaskan oleh variabel lain diluar penelitian.

\section{REKOMENDASI KEBIJAKAN}

\section{Rekomendasi}

Berdasarkan hasil pengujian data yang diproses SPSS Versi 23 sesuai dengan tujuan penelitian ini, maka rekomendasi hasil penelitian ini antara lain :

1. Secara parsial, penerapan SAP Berbasis Akrual berpengaruh signifikan terhadap pengambilan keputusan internal sebesar $54,4 \%$.

2. Secara parsial, penerapan SAP Berbasis Akrual berpengaruh signifikan terhadap kualitas pelaporan keuangan pemerintah daerah sebesar $59,7 \%$.

\section{Kebijakan}

Bedasarkan hasil dan interpretasi penelitian ini, maka peneliti memberikan saran sebagai rekomendasi kebijakan antara lain :

1. Penelitian selanjutnya dapat memberikan gambaran lebih luas mengenai pengaruh penerapan SAP berbasis akrual dalam pengambilan keputusan internal dan kualitas pelaporan keuangan seperti menjabarkan determinan yang mempengaruhi masing-masing variabel dan memperluas sampel dari SKPD Kota Bandung selain dinas dan badan

2. Bagi Satuan Kerja Perangkat Daerah (SKPD) Kota Bandung dalam meningkatkan kualitas pelaporan keuangan daerah disarankan untuk menerapkan kebijakan akuntansi yang sama dari tahun ke tahun. Selain itu, Satuan Kerja Perangkat Daerah (SKPD) Kota Bandung melakukan pencatatan kewajiban sesuai dengan nilai nominal dan meningkatkan nilai informasi yang tercantum di dalam laporan keuangan sehingga dapat membuat keputusan terkait investasi

\section{DAFTAR PUSTAKA}

Andhayani, A. (2017). Dilema Akrualisasi Akuntansi Dalam Pengelolaan Keuangan Daerah. Jurnal Akuntansi Multiparadigma Vol 8 No 2, 227-429. 
Andriani, Y., Kober, R., \& Juliana, d. (2010). Decision Usefulness of Cash and Accrual Information: Public Sector Managers' Perceptions. Australian Accounting Review No 53 Vol 20.

Andriyawan, Dea (2019, 12 Agustus). Pemkot Bandung Akselerasi LPPD di Tingkat Nasional. Bisnis [online]. Tersedia: https://bandung.bisnis.com/read/20190812/549/1135347/pemkotbandung-akselerasi-lppd-di-tingkat-nasional [Diakses: 29 September 2019]

Angelicca, Maya. (2019). Pengaruh Penerapan Standar Akuntansi Pemerintah Terhadap Kualitas Pelaporan Keuangan Daerah. Skripsi Sarjana pada: Repository Universitas Sanata Dharma: tidak diterbitkan.

Anggriawan, F. T., \& Yudianto, I. (2018). Factors Affecting Information Quality of Local Government Financial Statement. Journal of Accounting Auditing and Business Vol 1 No 1.

BPK.2017. Laporan Hasil Pemeriksaan LKPD Provinsi Jawa Barat Tahun Anggaran 2012-2017. bandung.bpk.go.id. Tersedia: https://bandung.bpk.go.id/?p=9923 [Diakses September 18, 2019]

Cahyo, F. (2015). Kualitas Laporan Keuangan Pemerintah Daerah: Faktor yang Mempengaruhi dan Implikasi Kebijakan (Studi Pada SKPD Pemerintah Provinsi Jawa Tengah). Jurnal Bisnis dan Ekonomi , 188-200.

Calmel, M.-P. (2017). France Supports Accrual Accounting. Account Econ Law 7(2), 125-129.

Fatmawati, R., \& Setiawan, D. (2018). Dampak Pengendalian Intern dan Ketepatan Informasi Terhadap Kebermanfaatan Akuntansi Akrual: Studi pada Pemerintah Daerah . Jurnal Dinamika Akuntansi dan Bisnis Vol 5 (2), 137-150.

Ferryono, B., \& Sutaryo. (2017). Manfaat Akuntansi Basis Akrual dan Akuntansi Basis Kas Menuju Akrual dalam Pengambilan Keputusan Internal Pemerintah Daerah. Jurnal Dinamika Akuntansi dan Bisnis Vol 4 No 1, 143-160.

Fitri, Y. (2018). Analysis of Factors Affecting The Quality Of Government Financial Statements Of Binjai City with Work Motivation as Moderating Variables. Jurnal IImiah FEB UB Vol 5 No 2.

Ghozali, I. (2016). Aplikasi Analisis Multivariate dengan Program IBM SPSS 25. Semarang: Badan Penerbit Universitas Diponegoro.

Karno, P. (2017). Kegunaan Informasi Akuntansi Dalam Pengambilan Keputusan Internal Oleh Unit Akuntansi Kuasa Pengguna Anggaran. Indonesian Treasury Review Vol 2 No 4.73-91.

Kriyantono, R. P. (2014). Kualitas Penelitian Kualitatif. Materi Metode Penelitian.

Kusumo, G. R. (2018). Analisis Faktor-Faktor yang Mempengaruhi Kualitas Laporan Keuangan Pemerintah Daerah (Studi Empiris pada Satuan Kerja Perangkat Daerah Kabupaten Bantul). Skripsi Sarjana pada: Dspace Universitas Islam Indonesia: tidak diterbitkan.

Najati, I., \& Pituringsih, E. d. (2016). Implementasi Akuntansi Berbasis Akrual : Pengujian Determinan dan Implikasinya Terhadap Kualitas Laporan Keuangan Kementrian/Lembaga. Lembaga Jurnal Akuntansi Universitas Jember 14.1.

Pejabat Pengelola Informasi dan Dokumentasi. Daftar Dinas Pemerintah Kota Bandung. Tersedia: https://ppid.bandung.go.id/kb/ppid-pembantu/dinas/ [Diakses pada 9 November 2019] 
Pejabat Pengelola Informasi dan Dokumentasi. Daftar Badan Pemerintah Kota Bandung. Tersedia https://ppid.bandung.go.id/kb/ppid-pembantu/badan/ [Diakses pada 9 November 2019]

Perdana, Putra P (Juni 20, 2019). Defisit Anggaran Rp 609 M, TKD PNS Kota Bandung Dipotong. bandung.kompas.com. Tersedia. https://bandung.kompas.com/read/2019/06/20/15594281/defisit-anggaran-rp-609-m-tkd-pnskota-bandung-terancam-dipotong [Diakses pada 10 Januari 2020]

Pujanira, P., \& Taman, A. (2017). Pengaruh Kompetensi Sumber Daya Manusia, Penerapan Standar Akuntansi Pemerintahan, Dan Penerapan Sistem Akuntansi Keuangan Daerah Terhadap Kualitas Laporan Keuangan Pemerintah Daerah Provinsi DIY. Jurnal Nominal, 1428.

Purwanti, L. (2017). Apakah Standar Akuntansi Pemerintahan Berbasis Akrual Membawa Berkah? Jurnal Akuntansi Multiparadigma JAMAL Vol 9 No 1, 173-191.

Rahmah, K., \& Zulkifli. (2018). Pengaruh Penerapan SAP Berbasis Akrual dan Sistem Akuntansi Keuangan Daerah Terhadap Kualitas Laporan Keuangan Pemerintah Daerah Kabupaten Gunung Kidul. Jurnal Kajian Bisnis Vol 26 No 2, 113-130.

Republik Indonesia. 2013. "Peraturan Menteri Dalam Negeri No. 64 Tahun 2013 tentang Penerapan Standar Akuntansi Pemerintahan Berbasis Akrual Pada Pemerintah Daerah."

---. 2005. "Peratutan Pemerintah (PP) No 24 Tahun 2005 tentang Standar Akuntansi Pemerintahan."

---. 2005. "Peraturan Pemerintah (PP) No. 58 Tahun 2005 tentang Pengelolaan Keuangan Daerah."

----. 2010. "Peraturan Pemerintah (PP) No. 71 Tahun 2010 tentang Standar Akuntansi Pemerintahan (SAP)."

Riadi, Tri Joko (2019, 20 Juni). Defisit Pemkot Akibat Ketidakcakapan Perencanaan Anggaran. Pikiran Rakyat [online]. Tersedia: https://www.pikiranrakyat.com/bandungraya/2019/06/20/defisit-pemkot-akibat-ketidakcakapan-perencanaan-anggaran September 2019]

Rosadi, Dian. (2017, Februari 6). APBD Kota Bandung 2017 defisit Rp 216 miliar. merdeka.com [online]. Tersedia: https://m.merdeka.com/bandung/halo-bandung/apbd-kota-bandung-2017defisit-rp-216-miliar-170206e.html [8 Januari 2020)

Salam, A., \& Sutaryo. (2019). Kesesuaian Sistem Pelaporan Keuangan Akrual Dalam Pengambilan Keputusan Internal di Pemerintah Daerah. ASSETS, Jurnal Akuntansi dan Pendidikan Vol 8 No 1, 21-34.

Sari, D. P., \& Putra, H. S. (2012). Menelisik Akuntansi Pemerintahan Berbasis Akrual. JEAM, XI (2), 33-56.

Solehudin, M. (2019, 28 Mei). Pertama Kali Dalam Sejarah, Kota Bandung Akhirnya Raih WTP. detikNews. [online]. Tersedia: https://news.detik.com/berita-jawa-barat/d-4567714/pertamakali-dalam-sejarah-kota-bandung-akhirnya-raih-wtp [8 Januari 2020]

Sudarsono, G., \& Darsono. (2017). Pengaruh Sistem Pengendalian Intern, Kompetensi Sumber Daya Manusia dan Penerapan Sistem Akuntansi Keuangan Daerah Terhadap Pelaporan 
Keuangan Pemerintah Daerah Kab. Grobogan (Studi Persepsi Pegawai SKPD di Kabupaten Grobogan). Diponegoro Journal of Accounting Vol 6 No 2, 1-10.

Sugiyono. (2018). Metode Penelitian Kuantitatif Kualitatif dan R\&D. Bandung: CV Alfabeta.

Suhartanto. (2013). Efektivitas Laporan Keuangan Pemerintah Daerah Dalam Mendukung Pengambilan Keputusan Manajemen Pemerintah Daerah. Pusdiklat Pengawasan BPKP.

Sujarweni, V. W. (2015). Metodologi Penelitian Bisnis \& Ekonomi. Yogyakarta: PUSTAKABARUPRESS.

Sukma, F., \& Sari, V. F. (2017). Analisis Manfaat Basis Akrual dan Basis Kas Menuju Akrual Dalam Pengambilan Keputusan Internal Pemerintah Daerah (Studi Empiris Pada OPD Di Kota Padang). Jurnal WRA No 2.

Trihani, I. (2017). Analisis Manfaat Basis Akrual dan Basis Kas Menuju Akrual dalam Pengambilan Keputusan Internal. Jurnal FE Universitas Negeri Padang Vol 6 No 1. 